\title{
49
}

\section{The End of Ramism: And the Shape of Things To Come}

\author{
Craig Collins ${ }^{1}$
}

\section{Introduction}

In his opening address to the National Law Reform conference, Michael Kirby, from his vantage point spanning several decades and by reciting a few lines from W B Yeats's Sailing to Byzantium, perfectly captured the conference theme as:

set upon a golden bough to sing

To lords and ladies of Byzantium

Of what is past, or passing, or to come. ${ }^{2}$

From the vantage point of a golden bough set high above the terrain bounded by 500 years of Western university and legal education, this chapter speaks of Ramism as something past and something passing. It also postulates what, in the digital age, is still to come. As Kirby observed, all of this is pretty fundamental to what legal academics do and how we do it. ${ }^{3}$

1 Senior Lecturer, Legal Workshop, The Australian National University; craig.collins@anu.edu.au. 2 William Butler Yeats, Sailing to Byzantium (Poetry Foundation, 15 April 2016), www. poetryfoundation.org/poem/172063; recited by Michael Kirby, 'Plenary Address' (Speech delivered at The National Law Reform Conference, Canberra, 14 April 2016).

3 Kirby, above n 2. 
Ramism was a Renaissance movement which, by harnessing the power of letterpress printing, transformed university education. The Ramists introduced a new method which, by becoming so deeply entrenched over centuries, has sunk beneath our consciousness. The point in talking about the ending of something so seemingly obscure as Ramism is to raise awareness that our current method of university education does indeed have a beginning. Further, this method was born out of past technological innovation. And, with this technology becoming superseded, some quite profound implications follow for future method in university education.

Specifically, this chapter identifies three challenges to which legal education should be geared in the near-to-medium-term future:

1. becoming self-aware of, and detaching from, our Ramist imprinting;

2. reimagining and reshaping law curricula for a post-Ramist world; and 3. riding the wave of new media.

Given the extent of the technological shift which has already occurred, none of the above challenges are matters of choice, so much as challenges to our adaptive capacity. This chapter focuses on proposed legal and policy responses to these challenges, including recalibrating the requirements for admission to practice as an Australian lawyer. More particularly, the chapter argues for reducing the weighting attached to the 'academic requirements' - and expanding the 'professional legal education requirements' - as our single best policy response to the larger forces confronting legal education in Australia today.

To begin, it is useful for us to grasp how the last great wave of technological innovation transformed method in university education.

\section{The Renaissance Ramists}

Petrus Ramus was a Professor at the University of Paris from 1551 until about 1568. His book, Professio Regia, published posthumously in 1576, carries the first use of the Latin word 'curriculum' ('race' or 'racecourse') in an educational context. For all that, as Adrian Johns says, '[a]mong the heroes of intellectual history, few can be less heroic' than Ramus. ${ }^{4}$ Walter

4 Adrian Johns, 'Foreword' in Walter Ong, Ramus: Method and the Decay of Dialogue (University of Chicago Press, first published 1958, 2004 edn) v. 
Ong describes Ramus as a 'shoddy scholar'. Johns refers to him 'at best $\ldots$ as an inveterate intellectual opportunist. At worst ... his ideas seem "close to the view of a madman". 5 At one time, the French King Francis I banned Ramus from teaching or publishing any philosophy due to his incompetence. ${ }^{6}$

Much to the chagrin of the scholarly elite, Ramus still succeeded in destroying the established Aristotelian-dialogical method of university education. His method harnessed the power of letterpress printing, reducing and simplifying knowledge as 'schema' and 'content' on the printed page and moving deductively and hierarchically from the general to the particular. Accordingly, in making logic spatial [the Ramists] in effect bound reason and memory to the kind of page that the press made. They turned books into containers of knowledge'. ' It now 'became possible for the ... university lecturer to focus the whole pedagogical economy on the spatial arrangement of material before his pupils' ${ }^{8}$ But this was a 'dry as dust' approach to curriculum which applied a crude logic and was 'orientated entirely to sight, not to sound':?

As a movement, it was by and large anti-dialogic, anti-dramatic, antipoetic, and anti-symbolic ... Dynamic, face-to-face interaction as the source of knowledge was 'eclipsed' $\ldots$ by the viewing of pages. This amounted to the inculcation of a new set of 'mental habits', prior to almost all reasoning, and upon which modern thought would rest. ${ }^{10}$

While there was a transitional struggle and rearguard action by traditionalists, within 'two generations, Ramism was becoming less evident, not because it ceased to exist, but because it had been incorporated into the standard organisational protocol for books themselves' ${ }^{11}$ As a concept, Ramism soon fell into obscurity because 'nobody argued about it any more. It had become second nature. ${ }^{12}$ And, of course, just as printing press technology proliferated, textbooks spread like wildfire - changing the shape of university education for centuries to come.

\footnotetext{
5 Ong, above n 4, 24.

6 Johns, above n 4, viii.

7 Ibid. vii.

8 Ibid.

9 Ibid. ix.

10 Ong, above n 4, 318.

11 Johns, above n 4, ix.

12 Ibid.
} 


\section{Challenge of the Common Law}

Ramists maintained that their pedagogy could be applied to '[a]ny conceivable subject - rhetoric, politics, law, history, biography, medicine, physics, mathematics' and so on. ${ }^{13}$ As Johns notes, ' $[t]$ heir ambition was to use this so-called 'method' to supplant university teaching in its entirety. And, remarkably enough, they more or less succeeded'. ${ }^{14}$

The kind of university law contemplated by Ramists was Roman and Canon law. Both presented a neat fit with Ramism, with deductive processes flowing down from higher, binding legal propositions and with the precision of Latin drawing sharp conceptual lines upon the page. English common law was rather different. For one thing, it was not the subject of university education until some two centuries after Ramus when Sir William Blackstone assumed the first Chair in Common Law at Oxford in 1757. Customary law followed a more inductive approach, flowing from the ground up. This was 'unwritten law' based upon a form of collective, social-habit memory. The role of lawyers was mainly confined to process and remedy, not so much reasoning about substantive law from first principles. Verdict and liability reposed within the hands of juries, which determined disputes without reasons. This kind of law would prove to be a very bad fit with Ramist pedagogy - and remains so to this day.

Blackstone was the first to try fitting the square peg of the common law into the round hole of a Ramist structure, eventually producing Blackstone's Commentaries on the Laws of England. In the absence of having any other schema to hand, he adopted the structure of Roman law texts. In doing so, Blackstone famously offered an architectural metaphor: comparing Roman Law with the fine symmetry and proportions of the classical style, and the common law inheritance with the rambling 'old Gothic castle', 'erected in the days of chivalry, but fitted up for the modern inhabitant'. ${ }^{15}$

Recognising the limitations of his own achievement, Blackstone said 'it is impracticable to comprehend many rules of modern law, in a scholarlike scientifical manner, without recourse to the antient'. Lawyers, too, regarded Blackstone's book as a crude and simplistic attempt to capture

\footnotetext{
13 Ibid. vii.

14 Ibid.

15 Carol Matthews, 'A "Model of the Old House": Architecture in Blackstone's Life and Commentaries', in Wilfred Prest (ed), Blackstone and His Commentaries (Hart Publishing, 2014) 33.
} 
the art and mystery of common law. Indeed, Michael Lobban has argued persuasively that attempts by Blackstone and Bentham to impose system and coherence upon the common law - by delineating positivist rules and narrow sources of law - were 'outside the mainstream of what lawyers thought the law was about'. ${ }^{16}$ Propelled further by John Austin, Professor of Jurisprudence at the University of London from 1826, legal positivism was an academic construct. Here was a tool for making the common law fit the square hole of a Ramist framework.

Ramism was further entrenched by the casebook method developed at the Harvard Law School by Professor Christopher Langdell in the 1870s. This approach was 'based upon generalisations - principles and categories of classification - from the data of reported cases'. ${ }^{17}$ The notion of legal science arose from applying Aristotelian logic to bounded casebook 'content', skewing learning towards the projected ruminations of appellate judges while marginalising the more practical, lawyerly preoccupations with process and remedy. This new method 'demanded a new cadre of academic specialists', ${ }^{18}$ as '[o]nly full time scientists can pursue legal science' ${ }^{19}$ within 'an autonomous field of knowledge'. ${ }^{20}$ In the United States, 'Harvardism - which by 1900 meant primarily the case method taught by a full time faculty ... spread to law schools everywhere'. ${ }^{21}$

\section{Late Ramists: Australian Legal Academics}

In Australia, until the 1960s, the predominant mode of legal education remained the apprenticeship model, through articles of clerkship. From then, with full-time law students and a new cadre of full-time legal academics growing in significant numbers, the Langdellian casebook method was adopted as the model of curriculum. The notion of law so framed was 'law as science'. As Nick James notes:

16 Michael Lobban, The Common Law and English Jurisprudence 1760-1850 (Clarendon Press, 1991) 13.

17 Robert Gordon, 'The Case For (and Against) Harvard' (1995) 93 Michigan Law Review 1231.

18 Ibid. 1234.

19 William La Piana, Logic \& Experience: The Origin of Modern American Legal Education (Oxford University Press, 1994) 57.

20 Gordon, above n 17, 1234.

21 Ibid. 1235. 
This approach to teaching law deemphasized the connections with legal practice and, at the same time maintained the separation of law from other disciplines in the university ... Legal scientism thus served to enhance and protect the discipline's new found academic credibility. ${ }^{22}$

Surveying the landscape in 2000, David Weisbrot suspected 'that if Professor Langdell walked into a contemporary law school in the United States or Australia ... he would feel right at home ... the nature of the core curriculum, the dominance of doctrine, and the basic approach to pedagogy have changed very little'. ${ }^{23}$

This also reflected the approach taken to prescribing the 'academic requirements' for admission to legal practice. This approach embodied a Ramist framework listing 11 categories of legal knowledge, with each category further subdivided from left to right across the page. Known as the 'Priestley 11', this would define textbook 'content' - as it continues to do so today. While the range of elective courses proliferated around this compulsory core, these were still shaped and delivered by the casebook method and Ramist pedagogy.

And so, with the Ramist notion of curriculum dating from the 1570s, it was only from the 1960s that Ramism strongly took hold in Australian legal education. As it happened, this was right at the tail end of the Ramist wave, just as the seeds of its own destruction were sparking into life. For, in 1969, the infant internet first 'spoke'. ${ }^{24}$

\section{The Internet Ends Ramism}

By the 1990s, John Perry Barlow, an early prophet of the digital age, was highlighting how the 'new wine' of information was rapidly being detached from the 'old bottles' of physical containment, such as books.

22 Nickolas James, 'A Brief History of Critique in Australian Legal Education' (2000) 24 Melbourne University Law Review 965, 968.

23 David Wiesbrot, 'What Lawyers Need to Know, What Lawyers Need to be Able to Do: An Australian Experience' (2000) Journal of the Association of Legal Writing Directors 21.

24 Agence-France Press, 'Internet Is 40 Years Young', The Sydney Morning Herald (online), 30 October 2009, www.smh.com.au/technology/technology-news/internet-is-40-years-young20091030-hp5d.html. 
'With the advent of digitization', he said, it became 'possible to replace all previous information storage forms with one meta-bottle: complex - and highly liquid - patterns of ones and zeros'. ${ }^{25}$

By 2000, while campaigning against copyright law's futile protection of 'old bottles', Barlow proclaimed that 'the great cultural war has broken out at last. Long awaited by some and a nasty surprise to others, the conflict between the industrial age and the virtual age is now being fought out in earnest'. ${ }^{26}$ In the face of this contest, the age of letterpress printing remains, to evoke Yeats, something passing - and virtually lost.

While the early phase of this cultural war is the tangible decline of books and the transfer of content online, this still presupposes a Ramist mental framework and traditional university curricula. But as digital natives grow in number across our teaching and learning spaces, a larger, more fundamental conceptual shift is emerging. Indeed, looking ahead, Microsoft founder Bill Gates has predicted as one of his four 'big bets' for the next 15 years that 'better software will revolutionise learning' and that 'online education will flourish'. ${ }^{27}$

\section{The Shape of Things to Come}

Marshall McLuhan described Ramus as "the first man in history to "surf" on a wave of information launched by new media'. ${ }^{28}$ This same opportunity is now presenting itself. If Ramism reflects a mentality made possible by letterpress printing, then what reconfigurations might cyberspace permit? McLuhan and Ong studied Renaissance Ramism with a view to better understanding the present. What can we learn from the past about the shape of things to come? From what direction will this new shape emerge?

Answering the first question invites reflection about all of those things left out by Ramism: the dialogic, dramatic, poetic and symbolic. Some balance needs to be restored towards sound and voice, including the value of dynamic, face-to-face interaction as a source of knowledge - now

25 John Perry Barlow, 'The Economy of Ideas' (1994) 2.03 Wired 1, archive.wired.com/wired/ archive/8.10/download.html.

26 Ibid.

27 Bill and Melinda Gates, 2015 Gates Annual Letter, www.gatesnotes.com/2015-annual-letter?WT. mc_id=01_21_2015_DO_com_domain_0_00\&page=0\&lang=en.

28 Johns, above n 4, ix. 
through synchronous interactions online. 'Interaction' is the key word, but of a kind different from eyeballing the page. New media permits multimedia engagement.

Reimagining the shape of law curricula requires some measure of selfawareness of, and detachment from, our Ramist imprinting. The bodily form of Ramism is not just the printed page, nor the Priestley 11. It is also carried by the biological wiring of our brains. In this way, Ramism might be understood as the imprint left upon our minds by so much learning and teaching from books and from the conventional shape of university curricula. Accordingly, modern academics are all Ramists. Indeed, there is probably no segment of humanity which is more invested in Ramism - and less interested in seeing learning in any other way - than university academics.

If the Renaissance is any guide, then the shape of new law curricula will be imagined and designed by 'inveterate intellectual opportunist(s)', much like Ramus himself. It is unlikely that innovation will be driven by elite professors and established academics, having built their success and reputations upon the foundations of a Ramist worldview. Even so, following the pattern of the past, it is a pretty sure thing that, within a generation or two, there will be few (if any) Ramists left.

\section{Initiation into the Discipline}

In Australia, we face a widening gulf between our system of university legal education and a legal profession necessarily driven by market responsiveness, global competition and rapid technological change. And yet reform debates still seem stuck within existing frameworks. By lifting our gaze to the horizon, arguing about the actual content of the Priestley 11 , and whether we should have a Priestley 12 and so on, seems almost as trivial as fighting over flapping fish stranded on a retreating shoreline just as a tsunami is gathering force out at sea.

For the profession, the opportunity is presented to reconceptualise accredited legal education in a manner which is far less 'Ramist remote' from the actual experience of entry-level lawyers. While tapping into the latest global developments in technology, education and learning psychology, the profession has a large role to play in reconstructing the entry pathway from the ground up. Rather than confining attention to 
the bounded terrain of 'content coverage', the real question is this: what qualities and capabilities are both necessary and desirable for human initiation into the discipline of law?

\section{Conclusion}

The above historical account has sought to situate Australian university legal education within the larger context of Ramist pedagogy and textbook method. It has also sought to present a case that we are, indeed, facing the end of Ramism. If this last proposition is accepted, then three particular challenges for university legal education seem to follow for the near-to-medium term future:

1. becoming self-aware of, and detaching from, our Ramist imprinting;

2. reimagining and reshaping law curricula for a post-Ramist world; and

3. riding the wave of new media.

In historic terms, the academic requirements for admission to practice as an Australian lawyer (the Priestley 11) were only recently devised and entrenched, reflecting a Ramist conception of knowledge and pedagogy. If the above account and identified challenges are accepted, then it is hard to imagine the validity and relevance of those academic requirements surviving the end of Ramism.

By contrast, the practical legal education requirements for admission to practice are far less shaped by Ramist pedagogy. Practical skill and knowledge, combined with professional values, have always been inculcated in other ways. The academic trajectory from Blackstone to the university law curricula of today, via the Langdellian casebook method, has only ever occurred in parallel with the more deeply-rooted community of discourse - the kind of mind and talk - by which lawyers themselves achieve mastery within the profession itself. New media offers opportunities for replicating online the kinds of interactions and support which propels this model of development. Indeed, with the vacuum left by the end of Ramism, the solution presenting itself is more akin to the way that lawyers have been learning and developing all along without it.

Accordingly, this chapter calls for recalibrating the regulatory balance in legal education - proposing that less weight be attached to the academic requirements and more weight to the practical legal education component - for the purposes of admission to practice as an Australian lawyer. 
NEW DIRECTIONS FOR LAW IN AUSTRALIA

Practical legal education, which seeks to replicate the nature of learning within the profession itself, remains a less encumbered, more grounded, innovative and adaptive space. And it is from this direction that law students will be much better placed to surf the wave of new media into the legal profession of the future. 
This text is taken from New Directions for Law in Australia: Essays in Contemporary Law Reform, edited by Ron Levy, Molly O’Brien, Simon Rice, Pauline Ridge and Margaret Thornton, published 2017 by ANU Press, The Australian National University, Canberra, Australia. dx.doi.org/10.22459/NDLA.09.2017.49 